\title{
Energy and nutrient recovery from agro-wastes: Rethinking their potential possibilities
}

\author{
Barkha Vaish ${ }^{1}$, Vaibhav Srivastava ${ }^{1}$, Prabhat Kumar Singh ${ }^{2}$, Pooja Singh ${ }^{3}$, Rajeev Pratap Singh ${ }^{1^{+}}$ \\ ${ }^{1}$ Department of Environment and Sustainable Development, Institute of Environment and Sustainable Development (IESD), Banaras Hindu University \\ (BHU), Varanasi-221005, India \\ ${ }^{2}$ Department of Civil Engineering, Indian Institute of Technology, Banaras Hindu University, Varanasi-221005, India \\ ${ }^{3}$ Department of Science, Institute of Computer Science and Technology, SHEPA, Varanasi-221005, India
}

\begin{abstract}
Agricultural sector has inescapably drawn attention towards itself due to growing concern over population explosion, changing climate and depletion of resources. Advancements in technology have caused rapid boost in farm productivity and hence huge production of agro-wastes. There have been massive deteriorating impacts of agro-wastes on existing environmental conditions, creating wide scale environmental pollution as well as biodiversity loss. Since, agro-wastes have huge potential in the form of energy and nutrient recovery (ENR), amalgamations of different technologies would promote sustainability. ENR not only adjoins an added profitable product but also facilitates to close environmental nutrient cycles. This provides a substitute to existing unsustainable approaches that are energy demanding and reliant on nonrenewable sources of energy. This review underpins why ENR from agro-waste must be key concern in production of array of higher value products.
\end{abstract}

Keywords: Agro-wastes, Energy, Nutrient Recovery (ENR), Technologies

\section{Introduction}

The energy predicament and dilapidation of environment are presently two vital issues for worldwide sustainable development [1]. The foremost source of potential energy is fossil fuels that are dominantly consumed by the most of developed and developing economies around the world [2, 3]. Dependence on traditional fuels has contributed to change in climate resulting in global warming $[4,5]$. Continuous increase in consumption of energy has led to rapid exhaustion of existing natural sources [6, 7]. Therefore, the world is looking for an energy system that is accessible, sustainable and clean lesser carbon intensive for survival and welfare of living beings [8, 9]. Simultaneously, the inconsiderate reality of a mounting global population forces rampant utilization of inorganic fertilizers. It degrades soil fertility, depletes soil organic matter, poses risk of soil erosion and through agricultural runoffs causes eutrophication. In this context, agricultural wastes/ agro-wastes that comprises straw, husk, stalks, cobs etc. embodies a profuse carbon-neutral feasible resource for bioenergy and nutrients generation as summarized in Fig. 1 [10].
Scientific advancement in genetics, biotechnology, engineering and process chemistry have yielded 'biorefinery,' a novel manufacturing concept. It converts renewable agro-wastes / biomass into biofuels, nutrients and by-products while integrating different technologies [11]. It offers the possibility for sustainable production of biopower and biomaterials [12, 13]. For biorefinery feedstocks, agro-waste provides potential substrate for recycling of nutrients in agricultural field which in turn maintain soil health, improves soil structure and reduces the risk of erosion. However, economic feasibility of the conversion processes is yet to be determined. Therefore, this review aims at better utility of agro-wastes, de-carbonization, biofuel generation, nutrient recycling and reduced pollutant emissions by actual application with holistic approach [14].

\section{Biorefinery Approach}

The increasing interest in biorefinery and the growing evidence for its benefits in terms of material savings and emissions reductions $[14,15]$, led to commensurate focus on biorefinery, particularly in
This is an Open Access article distributed under the terms of the Creative Commons Attribution Non-Commercial License (http://creativecommons.org/licenses/by-nc/3.0/) which permits unrestricted non-commercial use, distribution, and reproduction in any medium, provided the original work is properly cited.

Copyright (C) 2020 Korean Society of Environmental Engineers
Received June 24, 2019 Accepted October 16, 2019

${ }^{\dagger}$ Corresponding author

Email: rajeevprataps@gmail.com

Tel: +91-9935912997

ORCID: 0000-0001-9728-5361 
those countries and regions with large agri-food sectors [16]. In the design and operation of biorefineries, biofuels and nutrient recovery technologies have been a prime consideration that is utilized for recovering a range of $\mathrm{N}, \mathrm{P}$ or $\mathrm{K}$ rich products of environmental agricultural significance. A biorefinery may be considered as an integrated facility that employs extraction/conversion methods for the production of variety of platform chemicals, fuels, and energy that is somewhat parallel to a petroleum refinery $[17,18]$. Sustainability is the key criteria promoting bio-refineries which utilizes conversion of low-value biomass (specifically agro-wastes material from agriculture) into a portfolio of higher-value products to fulfill future product demands and must also be considered as an integral part of environmental management approaches [19, 20] (Fig. 2). Biorefinery feedstocks usually contain biomass having an excessive amount of carbon viz., lignocellulosic biomass obtained from agro-wastes that comprises mainly of carbon-rich polymers such as cellulose, hemicellulose, and lignin. It also contains nutrients like $\mathrm{N}, \mathrm{P}$, and $\mathrm{K}$ recovered from any type of agro-wastes [17] (Table 1).

Nutrients recovered from agricultural wastes can include complex organic mixtures, e.g, biomass; mixed residuals from thermo-chemical processes like char/ash; or separate N, P, K specific chemicals for e.g, $\mathrm{NH}_{4}{ }^{+}$or $\mathrm{K}$ based products [29]. Nutrient recovery technologies mainly include anaerobic digestion to produce biosolids, thermal processing to produce biochar or ash and aerobic composting to produce soil amendments. Char and ash are increasingly utilized in soil amendments which offer potential for heavy metal immobilization, carbon sequestration, and improved soil quality [30]. Potential technique for utilizing lignocellulosic agro-waste is by converting them into simple sugar (glucose) followed by fermentation to form ethanol [31, 32] (Fig. 3).

However, other solvents like butanol derived from biorefinery is equally useful or in some special cases superior to ethanol. But they have very limited public recognition. The superior qualities of butanol like low volatility, octane improving power, high energy content and miscibility could replace gasoline or diesel [34].

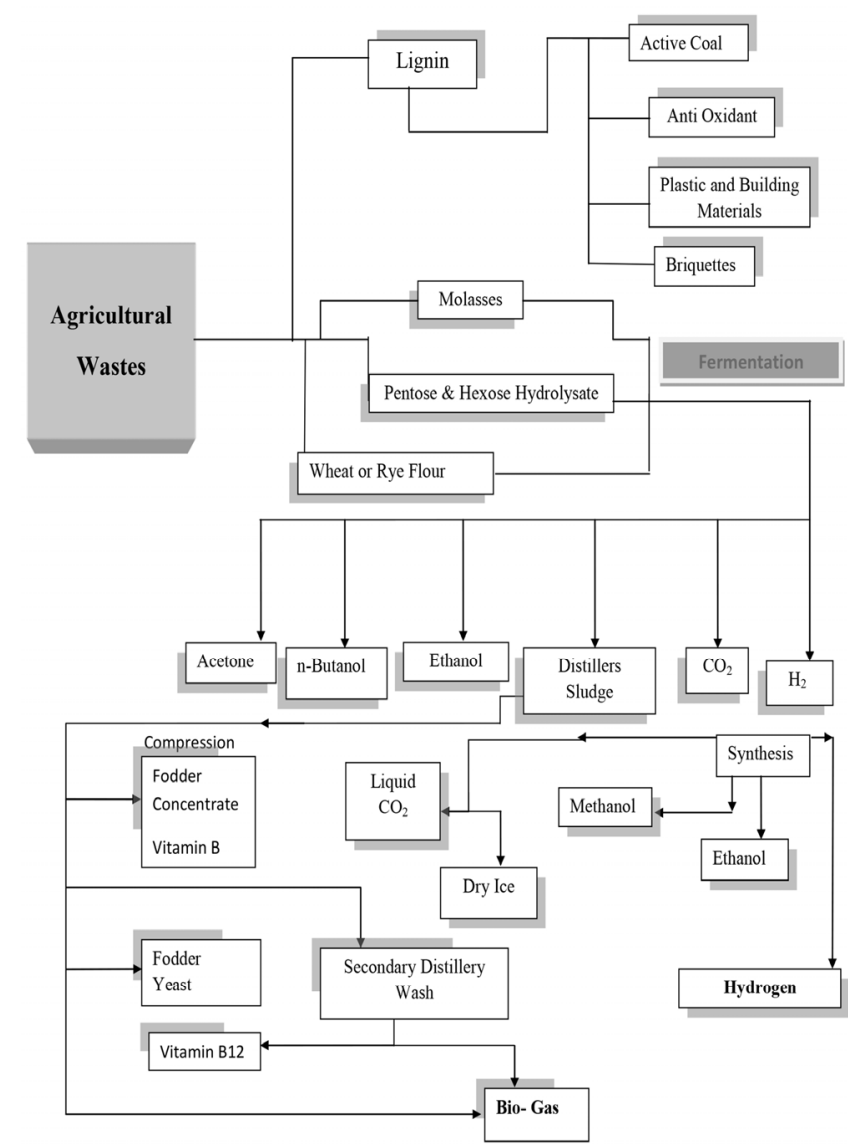

Fig. 2. Process of biorefinery concept with major substrates and products.

Economics is also favoring butanol fermentation with enhanced microbial stability and reduced product inhibition [35], and continuous improvements could be seen with efforts in

Table 1. Composition of Lignocellulose Component in Various Lignocellulogic Materials

\begin{tabular}{|c|c|c|c|c|}
\hline Lignocellulogic Materials & Lignin (\%) & Hemicellulose (\%) & Cellulose (\%) & Ref. \\
\hline Wheat Straw & $16.00-21.00$ & $26.00-32.00$ & $29.00-35.00$ & {$[21]$} \\
\hline Sugar cane Bagasse & 20.00 & 25.00 & 42.00 & {$[22]$} \\
\hline Corn Cobs & 15.00 & 35.00 & 45.00 & {$[23]$} \\
\hline Sweet Sorghum & 21.00 & 27.00 & 45.00 & {$[22]$} \\
\hline Corn Stover & 19.00 & 26.00 & 38.00 & {$[24]$} \\
\hline Hard Wood & $18.00-25.00$ & $24.00-40.00$ & $40.00-55.00$ & {$[25]$} \\
\hline Rice Straw & 18.00 & 24.00 & 32.10 & {$[23]$} \\
\hline Soft Wood & $25.00-35.00$ & $25.00-35.00$ & $45.00-50.00$ & {$[25]$} \\
\hline Nut Shells & $30.00-40.00$ & $25-30$ & $25-30$ & {$[26]$} \\
\hline Grasses & $10.00-30.00$ & $25.00-50.00$ & $25.00-40.00$ & {$[25]$} \\
\hline Bagasse & $23.00-33.00$ & 16.52 & 54.87 & {$[24]$} \\
\hline Banana Waste & 14.00 & 14.80 & 13.20 & {$[28]$} \\
\hline News Paper & $18.00-30.00$ & $25-40$ & $40-55$ & {$[26]$} \\
\hline Sponge gourd Fibre & $15.00-46.00$ & 17.44 & 66.59 & {$[27]$} \\
\hline
\end{tabular}




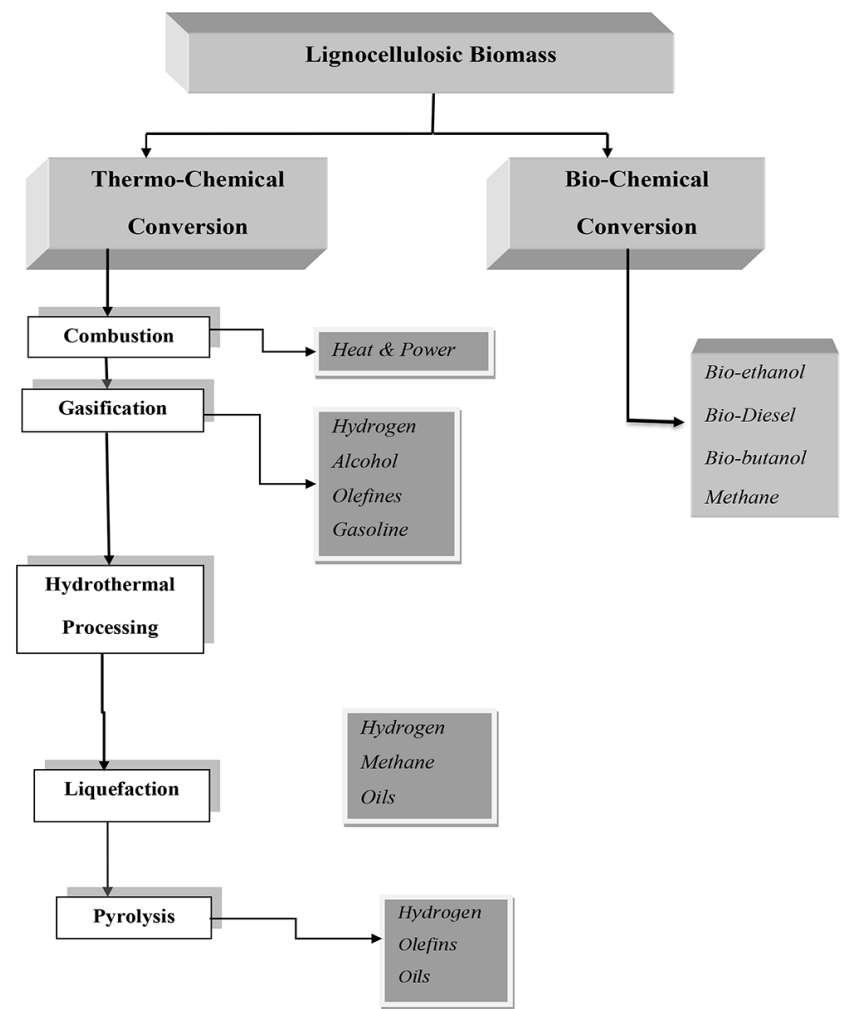

Fig. 3. Process flow chart of lignocellulosic biomass into various useful products [33]. research and development [36]. Therefore, possible efforts must be made to utilize each and every product of agro-waste. The experience gained must be used in building a modern mature technology for biofuel production which is economically and ecologically viable after petrol/oil era.

\section{Energy Recovery Possibilities}

Biorefineries are manufacturing services that transform bio-based materials into products like food, feed, fuels, chemicals, and energy [37]. These bio-based materials and chemicals could substitute products obtained from petroleum and natural gas [38, 39]. Moreover, they entail lesser investment and simple innovation technology while lessening air pollution from degradation of agro-wastes either when it is blazed in fields or when it is rotted in the countryside [40]. Moving towards renewable biomass resources is a progress of an industrial society that is sustainable and efficiently manages greenhouse gas emanations [13, 41]. The energy recovery potential of different agro-wastes adopted in different technologies is described in Table 2.

Although biofuels reduce fossil fuel driven energy problems and direct emissions [42], its increasing demand could cause an adverse environmental impact through changes in overall land utilization [43-45]. Production of biofuels might lead to loss of biodiversity either through straight displacement of natural habitat and/or meandering of ecologically valuable land [46, 47]. Therefore, biotechnological methods guiding biofuels production should be

Table 2. Energy Recovery Potential from Different Agricultural Waste in Different Regions of the World

\begin{tabular}{|c|c|c|c|c|c|c|c|c|c|c|}
\hline \multicolumn{11}{|c|}{ Energy Recovery } \\
\hline Country & Region & Income & Population & $\begin{array}{c}\text { Biomass Waste } \\
\text { generation } \\
\text { (tonnes/day) }\end{array}$ & $\begin{array}{c}\text { Biomass } \\
\text { energy source }\end{array}$ & Units & $\begin{array}{c}\text { Potential } \\
\text { Energy/ } \\
\text { bioelectricity }\end{array}$ & & $\begin{array}{l}\text { By the } \\
\text { year }\end{array}$ & Ref. \\
\hline Algeria & MENA & LMI & $19,225,335$ & 23,288 & Biomass & Mtoe & 3.7 & & - & [90] \\
\hline Brazil & LCR & UMI & $144,507,175$ & 149,096 & $\begin{array}{l}\text { Sugarcane } \\
\text { biomass }\end{array}$ & TWh & $62-93$ & & 2009 & [91] \\
\hline Finland & OECD & HIC & $3,301,950$ & 7,030 & $\begin{array}{l}\text { Agricultural } \\
\text { solid waste }\end{array}$ & $\mathrm{PJ} / \mathrm{yr}$ & 91 & & 2025 & [92] \\
\hline Germany & OECD & HIC & $60,530,216$ & 127,816 & $\begin{array}{l}\text { Agricultural } \\
\text { solid waste }\end{array}$ & $\mathrm{PJ} / \mathrm{yr}$ & 200 & & 2025 & [92] \\
\hline Norway & OECD & HIC & $3,605,500$ & 10,082 & $\begin{array}{l}\text { Agricultural } \\
\text { solid waste }\end{array}$ & $\mathrm{PJ} / \mathrm{yr}$ & 17 & & 2025 & [93] \\
\hline India & SAR & LMI & $1,358,137,719$ & 97,192 & Rice straw & $\mathrm{PJ} / \mathrm{yr}$ & 311.67 & & 2002 & [94] \\
\hline Thailand & EAP & UMI & $69,266,999$ & & Rice straw & $\mathrm{PJ} / \mathrm{yr}$ & 237.5 & $\begin{array}{r}\text { At } 100 \% \\
\text { - collection } \\
\text { efficiency }\end{array}$ & & \\
\hline Philippines & EAP & LMI & $104,256,076$ & & Rice straw & $\mathrm{PJ} / \mathrm{yr}$ & 141.8 & & & \\
\hline
\end{tabular}

OECD: Organization for Economic Cooperation and Development, SAR: South Asia Region, LIC: Low Income Countries, LMI: Low-Middle Income, HIC: High-Income Country, AFR: African Region, ECA: Europe and Central Asia,

LCR: Latin America and the Caribbean, EAP: East Asia and Pacific region, MENA: Middle East and North Africa region 
greatly accelerated that aptly use biomass recalcitrance agro-wastes while preventing biodiversity loss and taking care of sustainability criteria [48, 49]. However, huge demand of energy and fuel may not be fulfilled by biomass utilization due to relatively low energy content, seasonality and discrete geographic availability of biomass feedstocks [50, 51].

\subsection{Biogas/Methane Recovery}

Biogas consists of methane, carbon dioxide, hydrogen and hydrogen sulphide [52]. It is obtained in a bioreactor during biomethanation of organic substrates like sewage sludge, manure, agricultural residue, organic part of household and industrial wastes, along with energy crops [53]. Further, they are used as fuel for producing thermal energy and electricity [54, 55]. From a bioenergy point of view, the anaerobic treatment has an advantage over aerobic degradation of organic substrates as it yields high product (biogas) at low biomass input and results in less generation of waste sludge/ slurry [56, 57].

Agro-wastes are capable of biodegrading effortlessly owing to organic substance and low nitrogen content, making them appropriate for co-digestion and augmenting methane production with animal organic wastes from the fermenters [58, 59]. Significant studies on power generation from agro-wastes has been widely done. Considerable number of biogas plants are already running around the world. Developing nations like Brazil had already setup $85 \mathrm{MW}$ biogas plant from agro waste; $36 \mathrm{MW}$ from rice husk; $32 \mathrm{MW}$ from elephant grass; $371 \mathrm{MW}$ from wood residue [60]. Similarly, Piwowar et al. [61] studied agricultural biogas plants in Poland and found that production of biogas from agro-waste was increased by 137.29 million $\mathrm{m}^{3}$ from the year 2011-2014. Similarly, in developed nations like Germany, biogas plants are increasing continuously since last twenty years. There were approximately 140 biogas plants in 1992, while the number reached to 7720 at the end of 2013. For rural regions, development of market for establishment of biogas plants is crucial and must be analyzed for socio-economic and environmental aspects [62].

\subsection{Bioethanol}

The manufacturing of ethanol from agro-wastes derived sustainable resources is extended through the use of various microorganisms in fermentation systems [31]. These biofuels i.e. biomass to liquid are prepared from agro-industrial materials such as residues, straw, sawdust, reclaimed wood and low value timber [63, 64]. Bioethanol is a non-toxic substitute for traditional fossil fuel for transportation worldwide [65]. Along with energy generation, bioethanol is suitable for chemical feedstock and, as an industrial solvent [66]. There is also an increasing recognition that bioethanol provides environmental benefits to ease particulate emissions [67].

Recent studies have concluded that energy derived from agro-wastes has a completely positive energy balance to an extent that brings a prosperous impact on sustainability and security challenges [66]. For example, Dominguez-Bocanegra et al. [67] utilized coconut, pine and tuna as agricultural waste for promoting bioethanol production by yeast Saccharomyces cerevisiae CDBB 790. Their results showed that highest bioethanol concentration was in $22 \%(\mathrm{v} / \mathrm{v})$ pineapple juice, $20 \%(\mathrm{v} / \mathrm{v})$ coconut milk and least in tuna juice i.e. $12 \%$ (v/v). Similarly, Evcan and Tari [66] studied the apple pomace hydrolysate as agro-industrial waste co-culturing Aspergillus sojae, Trichoderma harzianum, and Saccharomyces cerevisiae. The highest ethanol and bioethanol concentration were $8.748 \mathrm{~g} \mathrm{~L}^{-1}$ and $0.945 \mathrm{~g} \mathrm{~L}^{-1}$, respectively. These preliminary studies suggest that bioethanol can be a treated as an alternative renewable feedstock for fossil fuel, as a feasible environmentally friendly solution for waste utilization.

\subsection{Briquette}

Briquettes obtained from agro-wastes are a biofuel substitute to coal and charcoal and can be employed in domestic cook stoves, boilers and gasifiers as fuel [49]. Briquettes are compressed/compacted blocks of coal dust or any other added combustible biomass like wood chips, charcoal, peat, cobs, straw, sawdust, and paper [68]. The fine quality briquettes are environmentally safe biofuels and are produced at low cost from solid waste - formed from agricultural and industrial sources, through thermo-chemical conversion [69-71]. Scattered and untreated waste biomass of high density is dried, chopped and compressed to make briquettes [72]. The technological options available for making biomass briquette fuel, compress scattered and untreated resources into fuel (solid) of high density through drying, chopping and briquetting [68], thus. This reduces transportation and storage space costs and also enhances the combustion quality, while making its activation more purposeful [73]. Briquettes from agricultural residues can be employed in power generation through gasification, straight ignition, co-combustion, and in industrial boilers, furnaces, heating boilers and other combustion equipment [74, 75]. The prospective economic, environmental and social impacts of biomass briquetting required appraisal to ensure its eco-efficiency. Studies focused on the techno-economic aspect of biomass briquetting have revealed that appliance of agro-waste for sustainable construction materials provide a solution which proposes conservation of energy and natural resources [76]. The extent of wastes produced from agro-sources like sugarcane bagasse, rice husk, jute fiber, etc. is relatively high. Thus, it can be strategically reused as a sustainable building material which could provide an alternative to excessive cost of conventional building materials along with nuisance of pollution and land-filling. Briquetting technology requires densification of material aimed at improvising its handling characteristics and hastening the volumetric calorific value [72]. Practically, the lignin content in biomass is useful for binding of particles [76]. Investigations on binderless briquettes using biomass waste have employed combination of pearl millet, saw dust, coal fines, jatropha shell, spent coffee grounds, paper pulp, bagasse, cotton stalk, [77, 78], rye straw along with meadow hay or leaves in 1:1 ratio [73,79], and were successfully reported to have approximate density ranging from 710 to $770 \mathrm{~kg} \mathrm{~m}^{-3}$. Therefore, briquetting may prove as an excellent and feasible option to refurbish the waste into valuable energy rather than leaving it to decompose at open dumps which may pollute the environment. Briquettes are easy to handle, can be easily stored or transported to long distances and do not cause any atmospheric crisis [68]. 


\subsection{Hydrogen Production by Dark Fermentation}

The environmental biorefinery is a unique concept where installations are designed to manufacture an extensive array of goods to increase biomass conversion. An unconventional fuel-hydrogen, is used as an energy carrier obtained from agro-lignocelluloses wastes so as to reduce dependency on fossil fuels, is being considered [80]. At present, the technology for biohydrogen production is not perfect as they are dependent on fossil fuels deviously through electricity generation [81]. Therefore, production of hydrogen by microbial action on wastes has immense potential for satisfying future energy demands through hydrogen production [82]. It is environment friendly as it decreases release of GHGs and other air pollutants. Biohydrogen can be employed as fuel for transportation in combustion engines and in fuel cells after purification for generating electricity. Its energy content per unit weight is as high as $142 \mathrm{~kJ} \mathrm{~g}^{-1}$ and the only by-product yielded through oxidative combustion is water [83]. This produces hydrogen as an environmental benefactor and may certainly substitute fossil fuels. Currently $88 \%$ of the marketable hydrogen originates from fossil fuels like natural gas, coal or heavy oils [84]. Until now, hydrogen is not commercialized as an energy source, but it is used simultaneously as a chemical reactant during production of fertilizers and refining. However, in large part, the proposal for using utilization of hydrogen as energy resource has been is constrained by high energy costs, storage space demand and distribution methods [81].

To enhance the likelihood of biohydrogen as a feasible system, water electrolysis has been developed which currently supplies up to $4 \%$ of total $\mathrm{H} 2$ production around the world [81]. While the production of biohydrogen from biomass at a laboratory research level has garnered enormous attention, though substantial technical advancement is required for its market to turn out to be cost-effective [85]. The competent sources of biohydrogen entail water bio-photolysis through green algae and cyanobacteria, photo-fermentation via photosynthetic bacteria, and dark fermentation by anaerobic bacteria [86, 87]. Similarly, biohydrogen production through carbohydrate fermentation is a novel approach and has received significant concern in recent years [88]. The main force for exploring the hydrogen production as a substitute of methane is its superior economic value and vast relevance in the biological processes that are eco-friendly and could satisfy future hydrogen demands from various renewable and carbon-neutral biomass resources [82, 89].

Considering that agro-wastes are decomposed biologically via complex microbial ecosystems or dark fermentation using crop residues food and livestock waste.

\section{Nutrient Recovery Possibilities}

During last few decades, research on sustainable recovery possibilities of nutrients has got much importance. Nutrients like nitrogen $(\mathrm{N})$, phosphorus $(\mathrm{P})$, and potassium $(\mathrm{K})$ are important for intensive agriculture and there are environmental concerns over their long-term availability and increasing costs [95]. Nitrogen is a renewable reserve whose extraction process (Haber-Bosch process) is energy intensive and its cost is dependent on availability of natural gas [96]. However, phosphorus rock is non-renewable reserve and also the chief source of phosphorus which is depleting at a progressively high rate. It has been speculated that the demand of phosphorus will surpass supply by the year 2033 [97]. Additionally, $90 \%$ phosphorus rock reserves are present in five countries viz., Algeria, China, Iraq, Morocco and Syria [88], and hence is a major challenge of food security for other nations. Similarly, prices for potassium-based fertilizers have increased four times during the years 2007-2009, and there are growing concerns for availability of potassium fertilizers in the developing economies. The reason is that their bulk distribution is found mainly in Canada and Europe and very limited distribution in rest of the world [98-99]. Therefore, other developing nations have little possibility to be self-sufficient in production of potassium through conventional fertilizers. In forthcoming decades, with the rise in global population, demand for food will increase that will create additional demand for alternative sources of nutrient recovery [100-102]. Therefore, there is an urgent need for integrated and holistic approach for recovery of nutrients. In this context, total amount of major nutrients (NPK) present in agro-wastes ranges from 40-100 kg tons ${ }^{-1}$. United states alone have 9 million tons year ${ }^{-1}$ of nutrients contained in agro-wastes and 74 million tons year ${ }^{-1}$ around the world [99]. Table 3 [103] highlights the nutrient values of diverse potential feedstocks/agro wastes.

To recover energy from agro-wastes, biological, physical and chemical techniques have been utilized in different countries as described in Table 4 [104]. Chemical techniques are limited to phosphorus accumulation, whereas biological methods are utilized for nitrogen and potassium accumulation and physical techniques are utilized for recovering all the three nutrients. However, a number of specific studies exist regarding the assessment of different nutrient recovery and reuse systems under different scenarios, still more uniform and widespread investigations are required. Yet proper research and knowledge are lacking about life cycle energy costs

Table 3. Nutrient Content of Various Potential Feedstocks/Agro Wastes [103]

\begin{tabular}{lccc}
\hline Feedstock/Agro Waste & $\begin{array}{c}\text { Nitrogen } \\
\text { (\%) }\end{array}$ & $\begin{array}{c}\text { Potassium } \\
\text { (\%) }\end{array}$ & $\begin{array}{c}\text { Phosphorus } \\
\text { (\%) }\end{array}$ \\
\hline Cereals (wheat) & 0.1 & 0 & 0 \\
Corn Cob & 1.38 & 0.46 & 0.09 \\
Corn Grain & 2.15 & 0.42 & 0.34 \\
Corn Leaves & 1.30 & 1.48 & 0.21 \\
Corn Silage & 1.30 & 0.9 & 0.16 \\
Corn Stem & 0.84 & 1.23 & 0.09 \\
Rapeseed Crop Biomass & $3.3-5.4$ & 0 & 0 \\
Sugarcane Bagasse & 0.73 & 0 & 0 \\
Wood & $0.07-0.39$ & 0 & 0 \\
Water Hyacinth & 1.96 & 0 & 0 \\
Pine & 0.1 & 0 & 0 \\
Peach Leaves & 0 & 2.45 & 0.14 \\
Giant Brown Kelp & 1.22 & 0 & 0 \\
\hline
\end{tabular}


Table 4. Nutrient Recovery Potential From Different Agricultural Waste in Different Regions of the World

Nutrient Recovery

\begin{tabular}{|c|c|c|c|c|c|c|c|c|c|}
\hline Country & Region & Income & Population & $\begin{array}{l}\text { Biomass waste } \\
\text { used }\end{array}$ & Proportion Used & $\begin{array}{l}\text { Method used for } \\
\text { nutrient recovery }\end{array}$ & Nutrient recovered & Year & Ref. \\
\hline Czech Republic & ECA & HIC & $10,628,906$ & $\begin{array}{l}\text { Apple pomace } \\
\text { waste }\end{array}$ & $25 \%, 50 \%$, and $75 \%$. & Vermicomposting & $\begin{array}{c}\mathrm{N}=2.8 \%, \mathrm{P}=0.85 \% \\
\mathrm{~K}=2.3 \%\end{array}$ & 2014 & {$[137]$} \\
\hline India & SAR & LMI & $1,358,137,719$ & Coconut husk & $\begin{array}{l}80 \%, 90 \%, 100 \% \text { coconut husk } \\
\text { with poultry manure and pig } \\
\text { slurry }\end{array}$ & Vermicomposting & $\begin{array}{c}\mathrm{N}=1.27 \mathrm{~g} \mathrm{~kg}^{-1} \\
\mathrm{P}=1.4-9.7 \mathrm{~g} \mathrm{~kg}^{-1} \\
\mathrm{~K}=7.7-10.5 \mathrm{~g} \mathrm{~kg}^{-1}\end{array}$ & 2016 & [138] \\
\hline Iran & MENA & UMI & $82,565,364$ & $\begin{array}{l}\text { Crop Residue } \\
\text { (Rice, corn, wheat } \\
\text { and sugarcane) }\end{array}$ & $\begin{array}{c}5 \mathrm{~kg} \text { of substrate included with } \\
200 \text { adult epigamic } \\
\text { earthworms }\end{array}$ & Vermicomposting & - & 2015 & [139] \\
\hline Italy & ECA & HIC & $61,838,227$ & Agriculture waste & - & $\begin{array}{l}\text { Anaerobic digestate: } \\
\text { drying with acidic } \\
\text { recovery, stripping } \\
\text { with acidic recovery } \\
\text { and } \\
\text { membrane } \\
\text { separation }\end{array}$ & $\begin{array}{c}\text { Drying: } \\
\mathrm{N}=6.8 \mathrm{gN} / \mathrm{L} ; \mathrm{P}=0.8 \mathrm{gP} / \mathrm{kg} \\
\text { Membrane Technology: } \\
\mathrm{N}=3.35 \mathrm{gN} / \mathrm{L}, \\
\mathrm{P}=1.64 \mathrm{gP} / \mathrm{L}, \\
\text { Stripping process: } \\
\mathrm{N}=3.6 \mathrm{gN} / \mathrm{L} \\
\mathrm{P}=0.5 \mathrm{gP} / \mathrm{L} .\end{array}$ & 2017 & {$[140]$} \\
\hline Germany & OECD & HIC & $82,392,809$ & Digestate & 10 - $50 \mathrm{~L}$ of digestate & $\begin{array}{l}\text { Membrane-based } \\
\text { treatment chain }\end{array}$ & $\begin{array}{c}\mathrm{N}=4.4 \mathrm{kgNtotal} \cdot \mathrm{t}^{-1} \\
\mathrm{P}=1.95 \mathrm{kgP}_{2} \mathrm{O}_{5} \mathrm{t}^{-1} \\
\mathrm{~K}=3.98 \mathrm{kgK}^{+}\end{array}$ & 2018 & {$[141]$} \\
\hline Australia & EAP & HIC & $24,987,583$ & $\begin{array}{l}\text { Agro-industrial } \\
\text { residues }\end{array}$ & - & - & $\begin{array}{c}\mathrm{N}=246 \mathrm{kt} \mathrm{N}, \mathrm{P}=88 \mathrm{kt} \mathrm{P} \\
\mathrm{K}=359 \mathrm{kt} \mathrm{K}\end{array}$ & 2010 & {$[95]$} \\
\hline India & SAR & LMI & $1,358,137,719$ & Rice straw & $1 \mathrm{Kg}$ & Vermicomposting & $\begin{array}{c}\text { TOC }=32.2-52.8 \% \\
\text { decrease } \\
\mathrm{N}=10.56 \text { and } 18.58 \mathrm{~g} / \mathrm{kg} \\
\mathrm{K}=1.1-2.6 \text { times higher } \\
\text { with increment of } 169 \% \\
\mathrm{P}=36-166 \%\end{array}$ & 2018 & [142] \\
\hline Germany & OECD & $\mathrm{HIC}$ & $82,392,809$ & Agriculture waste & - & Membrane filtration & $\begin{array}{l}8 \mathrm{~kg} \mathrm{t}^{-1} \mathrm{~N} \text { total, } \\
5.5 \mathrm{~kg} \mathrm{t}^{-1} \mathrm{P}_{2} \mathrm{O}_{5} \\
10 \mathrm{~kg} \mathrm{t}^{-1} \mathrm{~K}_{2} \mathrm{O}\end{array}$ & 2018 & {$[141]$} \\
\hline
\end{tabular}

OECD: Organization for Economic Cooperation and Development, SAR: South Asia Region, LIC: Low Income Countries,

LMI: Low-Middle Income, HIC: High-Income Country, AFR: African Region, ECA: Europe and Central Asia,

LCR: Latin America and the Caribbean, EAP: East Asia and Pacific region, MENA: Middle East and North Africa region

of nutrient recovery and reuse systems (recovery, refining, transportation) and how such costs are compared to the use of mineral fertilizers (mining, processing, transportation).

\subsection{Phosphorus Recovery}

Phosphorus, a vital plant nutrient is also a necessary component of fertilizers which is needed for healthy growth of plants. Phosphate rock- a finite reserve, is rapidly exhausting on a global scale as it is possessed by a few countries. Therefore, it is conclusive to recover $\mathrm{P}$ from agro-waste to close anthropogenic phosphorus cycle so as to promote agricultural sustainability [105, 106]. However, agro-wastes have rabeen explored for phosphorus recovery while at least $6.4 \% \mathrm{P}$ wastage results from crop harvesting [107]. For this purpose, potential of microbes must be fully exploited as phosphorus recycling from agro-waste is in its infancy. In this direction, phototrophic and heterotrophic organisms work together to help in accumulation of vital nutrients [108]. Generally, proteobacteria like cyanobacteria, purple non-sulfur bacteria and polyphosphate accumulating organisms (PAOs) are utilized for accumulation of nutrients [109]. Presently, PAOs are most extensively utilized for accumulation of P i.e. $20-30 \%$ by weight [110] which has solids-retention time of 10 days that is called as polyphosphate $[80,111]$.

Another means to recover $\mathrm{P}$ is through struvite recovery [112]. It is helpful in recycling of vital nutrients. Different studies suggested that among different agro-waste, cattle manure is very successful in recovery of struvite [113, 114], followed by swine manure [108, $109,115,116]$, poultry manure [117], and lastly cattle urine [118]. Generally, farm wastes containing manures are abundant in $\mathrm{P}$ and $\mathrm{NH}_{4}{ }^{+}$, which is advantageous for struvite recovery. However, the composition depends on various conditions like manure handling, rearing conditions, animal species, storage and treatment methods. In a similar study by Kataki et al. [119] stated that P concentration ranges from $90-600 \mathrm{mg} \mathrm{L}^{-1}$ i.e. $90-200 \mathrm{mg} \mathrm{L}^{-1}$ in swine manures, $100-460 \mathrm{mg} \mathrm{L}^{-1}$ for dairy manure and $370-600 \mathrm{mg} \mathrm{L}^{-1}$ in poultry manure. 
Köse and Kivanç [120] conducted an experiment where calcium phosphate was recovered from calcinated waste eggshell. The recovery efficiency of phosphate was found to be $37.6 \%$. From current literature, it was concluded that phosphorus can be recovered from agro-wastes at rate of $90 \%$ as calcium phosphate or $95 \%$ via struvite precipitation [121, 122]. Also, membrane technologies like osmotic membrane bioreactor (OMBR) have been utilized for biological phosphorus recovery from agro-wastes [123]. Padrino et al. [124] observed the highest rate of theoretical phosphorus recovery potential in agro-waste residues was obtained when subjected to pre-treatment with ionic liquid and thermophilic anaerobic digestion. Similarly, Yan et al. [125] studied the effect of wheat and rapeseed straw mulch on NPK recovery and was used in cultivation of hybrid rice. They found that wheat and rapeseed straw mulch increased total NPK accumulation in rice plants by $1.81-10.79 \%, 2.70-42.21 \%$ and 16.41-17.92\%, respectively, consequently enhancing NPK utilization. Nonetheless, innovative ideas for nutrient recovery are considered for paradigm of the biorefineries, where the wastes from the one system must be entirely reinstated in the market as raw material [126].

\subsection{Nitrogen Recovery}

Excessive discharge of nutrients into water bodies leads to eutrophication [127] that causes water pollution and consequently leads to soil pollution. Therefore, to curb such environmental issues, recovery of nitrogen is a strategic measure. For this purpose, blue green algae (cyanobacteria) are most suitable for uptake of nitrogen [128]. Micro algae play a major part in nutrient recovery and adequate biomass is required for sufficient uptake. It is a well-established fact that uptake and reduction of $\mathrm{NO}_{3}^{-}$is a photosynthetically driven process in nitrogen sufficient conditions of cyanobacteria. This will implicate production of ammonium and carbon skeletons.

Other physico-chemical techniques for nitrogen recovery like ion exchange for $\mathrm{NH}_{4}{ }^{+}$and $\mathrm{NO}_{3}{ }^{-}$recovery, $\mathrm{NH}_{4}{ }^{+}$precipitation as struvite, $\mathrm{NH}_{3}$ adsorption, stripping and distillation are well established [129, 130]. The best approach for $\mathrm{N}$ recovery depends on the concentration and form of $\mathrm{N}$ i.e. $\mathrm{NO}_{3}^{-} / \mathrm{NO}_{2}^{-}$or $\mathrm{NH}_{3} / \mathrm{NH}_{4}{ }^{+}$. The only available technology to recover nitrate is anion exchange followed by precipitation as an inorganic salt of nitrate for application in agriculture [131]. Therefore, further research on less expensive promising technologies for nitrogen recovery definitely is considered on high priority. Conversely, other nitrogen recovery techniques are available like electrodialysis, and liquid gas stripping. Gas permeable membrane produces aqueous ammonia solution which is capable of utilization as manure or can be utilized for denoxification of emissions from exhausts in waste incinerators and power stations [132]. Further conversion of aqueous ammonia to solid inorganic fertilizers like $\mathrm{NH}_{4} \mathrm{NO}_{3}$ or $\left(\mathrm{NH}_{4}\right)_{2} \mathrm{SO}_{4}$ can also be achieved. In this respect, Hadas et al. [133] conducted an experiment to study the effect of decomposition rate of agro-waste (tobacco, rapeseed, rice hulls, corn and wheat residue) and nitrogen availability to soil. The results revealed that nitrogen recovery from tobacco was higher as compared to rapeseed residue. Rice, wheat and corn residues were comparatively recalcitrant; however, rice residue does not cause any nitrogen deficiency. Similarly, Fox et al. [134] conducted an experiment on dried mature tops of six legumes i.e. alfalfa (Medicago sativa L.), Fitzroy stylo (Stylosanthes scabra Vog., var Fitzroy), leucaena (Leucaena leucocephala Lam., deWit), round leaf cassia (Cassia rotundifolia Pers., var. Wynn), snail medic (Medicago scutellata L.), and vigna (Vigna trilobata L., var verde). They were introduced in soil @ $100 \mathrm{mg} \mathrm{kg}^{-1}$ soil and found that net $\mathrm{N}$ mineralization after twelve weeks ranged from $47 \%$ of added $\mathrm{N}$ for alfalfa and $11 \%$ of added $\mathrm{N}$ with cassia. Two legumes i.e. Fitzroy stylo and cassia residues contained less than $20 \mathrm{mg} \mathrm{kg}^{-1}$ of $\mathrm{N}$ for six weeks of the experiment. Similar study was conducted by Ladd et al. [135] on medic material residue (Medicago littoralis) that was amended with soil at 3 field sites in South Australia. Deliverables of around 189 $\mathrm{kg} \mathrm{N} \mathrm{ha}^{-1}$ was achieved during fifteen months of decomposition. Of this $49.3 \%$ was taken up by test plant wheat), $19.7 \%$ was immobilized or persisted as fine root residue, $9.2 \%$ was left as inorganic $\mathrm{N}$ in the soil while $22.1 \%$ was accounted for soil-plant interaction or may be lost through inorganic $\mathrm{N}$. Hence, around $6.5 \mathrm{~kg}$ inorganic $\mathrm{N} \mathrm{ha}^{-1}$ was provided by the amended soil with medic residues per $100 \mathrm{~kg}$ dry matter ha ${ }^{-1}$ removed as wheat grain. However, the economic feasibility of nitrogen recovery is very low due to its high chemical cost for adjusting $\mathrm{pH}$ to increase free ammonia concentration i.e. $\mathrm{NH}_{4}{ }^{+}$ to $\mathrm{NH}_{3}$, the requirement of heat for decreasing ammonia gas solubility, ammonia stripping, and lastly because of comparatively low cost of ammonia products derived from Haber-Bosch process.

\subsection{Potassium Recovery}

Potassium is another important nutrient for increasing crop yield and enriching soil. It is well acknowledged that nitrogen use efficiency, productivity and resistance to drought, pests and diseases are improved by potassium. Most parts of the world are under agricultural practices that grow potassium demanding crops like sugar beet, fodder crops, vegetables, potatoes, and other commercial crops. Forms of potassium that are accessible to plants from soil are exchangeable potassium and soil solution potassium. Soil Organic Matter (SOM) present in surface layer is a crucial factor that retains sufficient quantity of potassium, but SOM is rapidly diminishing in soils of tropical region.

Adeoye et al. [136] stated that potential to utilize resource of potash from agro-wastes is available in ample quantity. They assessed thirteen agro-wastes for their potassium and other nutrient contents. They found that plantain waste, cocoa waste, water hyacinth and market waste are high in K contents. Different amendments of such wastes were applied at the rate of @ $@ 0,10,15,20,25$, 30 tons/ha in powder form together with recommended dose of NPK were applied in greenhouse experiment on Amaranthus cruentus L. used as test crop. The results obtained showed that cocoa waste and water hyacinth supported maximum crop yield and growth when treated with 10 tons/ha, respectively. Growth and yield of crop were significant ( $p<0.05$ ) with respect to inorganic NPK fertilizer. It was also detected that potassium obtained from water hyacinth was more easily available to plant as compared to other farm wastes. Potassium from water hyacinth and cocoa waste possibly prove to be economical for farmers of the developing countries to fulfill their required potassium demands.

\subsection{Comlizers}

Comlizers are obtained by mixing composted organic waste and ammonium sulphate fertilizers [143]. It was first developed in Ghana 
and has been tested on maize crop and compared with application of NPK (15-5-15) and ammonium sulphate. Plots that were amended with comlizers@91 kg N ha ${ }^{-1}$ showed 11\% higher uptake of nitrogen and phosphorus than ammonium sulphate treated plots (a) $150 \mathrm{~kg} \mathrm{~N} \mathrm{ha}^{-1}$ and NPK treated plots (15-5-15). Also, the organic matter of soil amended with comlizer was 22 and $64 \%$ higher than the inorganic fertilizer and soil. Water use capacity was also $12 \%$ higher as compared to other treatments. Little threat was expressed from heavy metal and pathogens that must be considered for their elimination while practicing on larger scale. Therefore, application of comlizer improves nutrient uptake, crop yield, organic matter, and water use efficiency. Additionally, comlizers are relatively cheaper than other fertilizers available in the market [144].

\section{Energy and Nutrient Recovery: An Economic Assessment}

Currently, reconsideration of the effective exploitation of alternative uses of renewable resources through clean technologies is crucial. Also, it is essential to overcome the huge dependency on petroleum for liquid fuels. The selection of suitable feedstock and processes for generating clean energy and essential nutrients must be such which consume lesser electricity, generate less emission in total, and have low adverse human health impact [145]. Considering these factors and to fulfill the present-day energy and nutrients' need, lignocellulosic biomass obtained from agro-waste is considered as a most potential material. Furthermore, from the biorefinery concept, discovery and characterization of new enzymes through advanced technologies led to low-cost transformation of lignocellulosic biomasses into bio-fuels, bio-chemicals and bio-fertilizers [146-148].

\subsection{Economic Perspective on Energy Recovery}

The manufacturing of any product must be economically viable otherwise; marketing is not possible even if they are made from renewable resources. Time to time economic analysis has been carried out by many researchers and scientists on the potentiality of agro-residue in terms of energy recovery and valuation of their bio-products. Ethanol and bio-diesel are the most well-known forms of agro-fuels for gasoline and diesel substitution, respectively. In Brazil (2010), Portugal-Pereira et al. [60] reported that $8 \%$ of total electricity consumption was fulfilled by the bioenergy which is approximately equal to 39 TWh. Around 9 GW energy productions were estimated from agro-wastes in Brazil considering the average annual availability factor of $50 \%$. On the contrary, another study by Dassanayake and Kumar [149] indicates that electricity generation in Alberta by direct combustion of triticale straw is not reasonable at any plant scale as compared to coal based power generation.

They concluded that even at very low power cost of $\$ 71.57 / \mathrm{MW}$, triticale straw-based energy plant is not considered economically viable. Moreover, the presently available conversion technology is less efficient and logistics causes the triticale straw-based bio-en- ergy generation costlier in comparison to fossil fuel-based energy; however, it could become competitive with carbon credits.

Seabra et al. [150] carried out the economic analysis that involved evaluation of the minimum ethanol selling price (MESP) of sugarcane residual biomass. The total investment calculated for the biochemical conversion plant is around $152 \mathrm{M}$ \$ leading to final MESP values of $318 \$ \mathrm{~m}^{-3}$ for biochemical conversion while for thermochemical conversion the total value cost was $127 \mathrm{M} \$$ and MESP value of $329 \$ \mathrm{~m}^{-3}$ was achieved. Thermochemical conversion. Total electricity generation from biochemical conversion is 50 $\mathrm{kWh} \mathrm{t}^{-1}$ of cane of electricity surplus while from thermochemical conversion the values are reduced to $32 \mathrm{kWh} \mathrm{t}^{-1}$ of cane for electricity. However, the residues that cannot be converted into ethanol through biochemical conversion could lead to provide power at $557 \mathrm{kWh} \mathrm{m}^{-3}$ ethanol. Via biochemical route, the high amount of residues that cannot be converted into ethanol leads to a high potential to export power, at $557 \mathrm{kWh} \mathrm{m}^{-3}$ ethanol. Electricity would be an important co-product of this biorefinery plant, for bio chemical conversion, with surplus of about $50 \mathrm{kWh} \mathrm{t}^{-1}$ of electricity from cane.

Similarly, Yoosin and Sorapipatana [151] stated that the production costs of the bio-ethanol are quite variable due to highly volatile nature of the raw materials. and concluded that in general, of the total bio-ethanol production costs feedstock contributes 60-75\%. The cost of bio-ethanol from sugar cane is US\$ 0.23-0.29 per liter [152], whereas sugar and corn-based bio-ethanol in EU and the United States are reported to be $\$ 0.29$ per liter [153] and US\$ 0.53 per liter [154], respectively. The bio-ethanol production costs are commonly higher based on the energy content. Sugars and corn-based ethanol plants affect food production and also its production cost is higher which makes it difficult to become cost competitive with fossil fuels. Because of this serious economic concern, now majority of the industries are focusing on scientific research to develop economically viable lignocellulose-based biofuel energy plant.

\subsection{Economic Perspective on Nutrient Recovery}

The sustainable production of fertilizers, particularly NPK, are quite challenging in this century. To avoid toxic effect of chemically produced fertilizers on soil health, the biologically treated organic wastes are the best option which could augment the soil fertility. The best way to utilize large volume of nutrient rich agro-wastes is by recycling through appropriate biological processes like composting, vermicomposting or anaerobic digestate [155, 156]. Bekchanov and Mirzabaev [157] evaluated that recycling of agro-wastes through composting causes reduction of expenses from US\$ 357 to 197 million in total agro-waste management and fertilizer usage cost. However, investment costs of operating an anaerobic sludge composting plant (capacity of $7.12 \times 106 \mathrm{~kg}$ ) is around $€ 462,646$ and annual cost ranges between $€ 250,000$ - 360,000. Similarly, Dockhorn [158] assessed operating and maintenance costs of a phosphorus recovery plant from struvite (capacity 350,000-person equivalents (PE)). They concluded that with 50 $\mathrm{mg} \mathrm{L}^{-1} \mathrm{PO}^{4}-\mathrm{P}$ concentration, $€ 2800$ ton $^{-1}$ of struvite was achieved; however, with $800 \mathrm{mg} \mathrm{L}^{-1} \mathrm{PO}^{4}-\mathrm{P}$ concentration, only $€ 520$ ton $^{-1}$ was attained. In a similar study, Battistoni et al. [159] estimated 
total profits between $€ 7,800-89,400$ year $^{-1}$ from struvite production at operating costs of $€ 0.19-0.28 \mathrm{~m}^{-3}$ digestate. However, Blumenstein et al. [160] reported that from an investors' perspective composting of grasses from semi-natural grassland of Germany, Wales and Estonia was not profitable in comparison to generation of solid fuel and biogas from the biomass. In a precise case study, capital and operational costs for pre-treatment of anaerobic digestate, were estimated between 5.40 and $6.97 € \mathrm{~m}^{-3}$ by Bolzonella et al. [140]. However, the economic valuation of any plant is a complicated process due to many uncertainties on investments and operating costs. Further, research to evaluate risk and optimization of combination of technologies is needed.

\section{Strategic Action Plans for ENR}

\subsection{Regulatory Coherence and Policies}

Society is well aware of the problems generated due to anthropogenic activities. To tackle these problems, collective legislative actions and policies need to be framed. There are considerably large number of directives and regulations concerning ENR from agro-wastes. The legal framework on energy guarantees certainty to relevant stakeholders, administrative authorities, waste producers, disposal companies and citizens to know their roles and obligations. Appropriate framework is required to reach the objective of sustainability. Moreover, regular monitoring and legal binding is necessary for regulating emission standards and other environmental prescriptions.

However, there is a great range of corresponding regulation at national and regional level which can hinder entrepreneurial impetus, investment and knowledge transfer. Similarly, for greater uptake, recovery and reuse of nutrients and development, regulations governing the sectors need certain coherence between the member states. For instance, the European Union (EU) has created a significant assembly of regulation impacting nutrient use. The main elements that are to be regulated are consequential treatment of organic waste, their utilization in crop and livestock farming, nutrient market, and secondary raw materials arising from this complex chain [161].

Owing to substantial financial risk, poor implementation, and gaps in regulation requires primary concern. However, the problems have patently not been resolved despite collection of attempts have been made to deal with them. Therefore, full techno-economic assessment of local, regional and global recovery of energy and nutrients must be backed up by decision assistance tools.

Regulatory policy scheme of many countries promotes renewable energy technologies (RETs) and it is getting great importance now-a-days. Two most standard regulatory policies are Feed-in-tariff (FIT) and Renewable Portfolio Standard (RPS). Mostly, FIT and RPS are emphasized because they denote most widespread regulatory promotion policies [162, 163]. Theoretically, FIT is based on the price regulation policy in which producers of power is paid a fixed rate or premium for their electricity, irrespective of how much they can generate. Generally, for a definite duration of time the prices are fixed, however, the tariff may change with time. RPS is based on quantity regulation policy and valuation depends on market condition which decides the price for power generated. In this connection, governments fix targets or quotas to confirm that a certain market share of capacity or generation of electricity produces from renewable energy sources [164]. Earlier research work concluded that FIT is a better promoter of power capacity development than RPS [162, 164, 165 ]. However, these research conclusions are made on the basis of comparative case studies that lack vigorous empirical test.

Langniss and Wiser [166] studied the implication of national and sub-national policies. In the way of power development projects, they emphasized that FIT can make a stable and profitable market whereas in case of RPS there is a lack of surety in the market assurance and industrial profitability, henceforth, it provides fewer progresses in power generation. However, in previous studies by Mitchell [167] and Menanteau et al. [168] indicated that RPS is more liable to incentivize competition between different renewable technologies whereas FIT does not inspire innovation since it promises stable prices to producers. Other studies from the environmental and economic aspects, market-based approach is considered as superior to a non-market system in promotion of technological change [169-172]. From the energy point of view, RPS is categorized as market-based policy whereas FIT is focused on price control by government. Therefore, RPS appears to be more ideal according to this standard of comparison.

\subsection{Recommendations}

Following recommendations regarding framing of policies can be adopted:

a. Technologies to lower the cost of implementation of energy recovery plants must be encouraged.

b. The cost and financial aspect must be critically assessed to encourage energy plants in developing nations.

c. Advancement in emission control technologies from energy generation through wastes should be taken into prime consideration.

d. Technical specifications, emission standards, suitable waste, extraction process for energy as well as cost benefit analysis must be clearly defined.

e. Frequent interaction with environmentalists, stakeholders, municipality and local people must be done for operational health and safety measures.

f. Adequately qualified and skilled staff members must be provided for effective enforcement and regular inspections.

g. Manage nutrient cycle in a resource efficient way by promoting sustainable management of agricultural ecosystems.

h. Governments need to end harmful farming practices of intensification and switch to sustainable agricultural practices.

I. Tax must be levied for excessive pesticides and fertilizers usage.

j. Polluter pays principle must be implemented for ensuring cost recovery.

k. For overall release of nitrogen and other nutrients, local targets must be set keeping in view the ecological limits.

l. Regular monitoring of quality standards, both for energy and nutrient recovery strongly implemented. 


\section{Conclusions}

The recovery of energy and nutrients from agro-waste must be ensured that they are consistent in competition with current technologies [175]. Amalgamation of different technologies may help in enhancing the use of agro-wastes for centralized ENR. However, socio-economic, logistical, regulatory, political etc. barriers create a gap between the sustainable, technical and economic potentials of energy and nutrient recovery. Presently, for fertilizer industries, new prospects arise to move from inorganic fertilizers, to organic fertilizers that augment soil health. Synchronization of small and medium farmers into cooperatives as well as application of energy service companies (ESCOs) for financing in ENR would lessen operational costs. Also, commercial incentives such as FIT and RPS would reassure stakeholders to expand their activities together with bioenergy in their business portfolio. Overall, development of respective technologies for ENR from agro-wastes must be implemented for the secondary market. Thus, this paper outlined the importance of energy and nutrient recovery of higher quality from agro-wastes that counteracts present problems of wasteful energy use, environmental degradation and nutrient resources depletion.

\section{Acknowledgement}

The authors are thankful to the Dean \& Head, Department of Environment and Sustainable Development and Director, Institute of Environment and Sustainable Development, Banaras Hindu University, for providing necessary facilities. RPS is thankful to Department of Science \& Technology for providing financial support (DST-SERB P07-678). BV is also thankful to Council of Scientific \& Industrial Research for awarding Senior Research Fellowship.

\section{References}

1. OECD. Annual Report on Sustainable Development Work in the OECD [Internet]. Paris: OECD; c2008. Available from: http://www.oecd.org/publishing/corrigenda.

2. Singh RP, Sharma B, Sarkar A, Sengupta C, Singh P, Ibrahim $\mathrm{MH}$. Biological responses of agricultural soils to fly-ash amendment. Rev. Environ. Contam. Toxicol. 2014;232:45-60.

3. Zou C, Zhao Q, Zhang G, Xiong B. Energy revolution: From a fossil energy era to a new energy era. Natural Gas Ind. B. 2016;3:1-11.

4. Srivastava V, Ismail SA, Singh P, Singh RP. Urban solid waste management in the developing world with emphasis on India: challenges and opportunities. Rev. Environ. Sci. Bio. 2015;14: 317-337.

5. Vaish B, Singh P, Kothari R, Srivastava V, Singh PK, Singh RP. The potential of bioenergy production from marginalized lands and its effect on climate change. Climate Change Environ. Sustain. 2016;4:7-13.

6. Singh RP, Tyagi VV, Allen T, Ibrahim MH, Kothari R. An over- view for exploring the possibilities of energy generation from municipal solid waste (MSW) in Indian scenario. Renew. Sustain. Energ. Rev. 2011;15:4797-4808.

7. Oyedepo SO. Energy and sustainable development in Nigeria: the way forward. Energ. Sustain. Soc. 2012;2:15.

8. Wang J, Zhao J, Deng S, et al. Integrated assessment for solar-assisted carbon capture and storage power plant by adopting resilience thinking on energy system. J. Clean. Prod. 2019;208: 1009-1021.

9. Vaish B, Singh P, Singh PK, Singh RP. Biomethanation potential of Algal biomass. Springer International Publishing; 2017. P.331-346.

10. Du C, Li Y, Zhao X, et al. The production of ethanol from lignocellulosic biomass by Kluyveromyces marxianus CICC 1727-5 and Spathaspora passalidarum ATCC MYA-4345. Appl. Microbiol. Biot. 2019;103:1-11.

11. da Silva ARG, Errico M, Rong BG. Systematic procedure and framework for synthesis and evaluation of bioethanol production processes from lignocellulosic biomass. Bioresour. Technol. Reports. 2018;4:29-39

12. Bhatia L, Johri S, Ahmad R. An economic and ecological perspective of ethanol production from renewable agro waste: A review. Amb. Exp. 2012;2:65.

13. Vaish B, Srivastava V, Singh P, Singh A, Singh PK, Singh RP. Exploring untapped energy potential of urban solid waste. Energ. Ecol. Environ. 2016;1:323-342.

14. Ahuja D and Tatsutani M. Sustainable energy for developing countries. SAPI EN. S. 2009;2:1-16.

15. Mitchell P, Morgan J. Employment and the circular economy job creation in a more resource efficient Britain. [Internet]. London: Green Alliance; c2015. Available from: http://www. green-alliance.org.uk/resources/Employment\%20and\% 20the\%20circular\%20economy.pdfMitchell.

16. Mitchell P, Doherty M. Job Creation in the circular economy-increasing resource efficiency in Northern Ireland. 2015. Available from Belfast: http://www.wrap.org.uk/sites/files/wrap/ReNEW\% 20CE\%20Employment\%20Report.pdf.

17. Blades L, Morgana K, Douglas R, et al. Circular Biogasbased Economy in a Rural Agricultural Setting. In: $1^{\text {st }}$ International Conference on Sustainable Energy and Resource Use in Food Chains. 19-20 April 2017; Berkshire, UK.

18. Naik SN, Goud VV, Rout PK, Dalai AK. Production of firstand second-generation biofuels: a comprehensive review. Renew. Sust. Energy. Rev.2010;14:578-597.

19. Kwon E, Jeon EC, Castaldi MJ, Jeon YJ. Effect of carbon dioxide on the thermal degradation of lignocellulosic biomass. Environ. Sci. technol. 2013;47:10541-10547.

20. Anex RP, Lynd LR, Laser MS, Heggenstaller AH, Liebman M. Potential for enhanced nutrient cycling through coupling of agricultural and bioenergy systems. Crop. Sci. 2007;47:1327-1335.

21. Ramesh D, Muniraj IK, Thangavelu K, Karthikeyan S. Chemicals and Fuels Production from Agro Residues: A Biorefinery Approach. 2019. Springer, Cham Vol 7. In: Srivastava N, Srivastava M, Mishra P, Upadhyay S, Ramteke P, Gupta V. eds. Sustainable Approaches for Biofuels Production Technologies. Biofuel and Biorefinery Technologies.

22. McKendry P. Energy production from biomass (part 1): overview 
of biomass. Bioresour. Technol. 2002;83:37-46.

23. Kim M and Day DF. Composition of sugar cane, energy cane, and sweet sorghum suitable for ethanol production at Louisiana sugar mills. J. Ind. Microbiol. Biot. 2011;38:803-807.

24. Prasad S, Singh A, Joshi HC. Ethanol as an alternative fuel from agricultural, industrial and urban residues. Resour. Conserv. Recy. 2007;50:1-39.

25. Zhu Y, Lee YY, Elander RT. Optimization of dilute- acid pretreatment of corn stover using a high-solids percolation reactor. Appl. Biochem. Biotech. 2005;124:1045-1054.

26. Malherbe S, Cloete TE. Lignocellulose biodegradation: Fundamentals and applications. Rev. Environ. Sci. Biol. 2002;1:105-114

27. Howard RL, Abotsi ELJR, Van Rensburg EJ, Howard S. Lignocellulose biotechnology: Issues of bioconversion and enzyme production. Afr. J. Biotechnol. 2003;2:602-619.

28. Guimarães JL, Frollini E, Da Silva CG, Wypych F, Satyanarayana KG. Characterization of banana, sugarcane bagasse and sponge gourd fibers of Brazil. Ind. Crop. Prod. 2009;30:407-415

29. John FMG, Medina PIV, Ruiz CAA. Ethanol production of banana shell and cassava starch. Dyna Rev. Fac. Nac. Minas. 2006;73:21-27.

30. Kwon EE, JeonYJ, Yi H. New candidate for biofuel feedstock beyond terrestrial biomass for thermo-chemical process (pyrolysis/gasification) enhanced by carbon dioxide $\left(\mathrm{CO}_{2}\right)$. Bioresour. Technol. 2012;123:673-677.

31. Beesley L, Moreno-Jiménez E, Gomez-Eyles JL, Harris E, Robinson B, Sizmur T. A review of biochars' potential role in the remediation, revegetation and restoration of contaminated soils. Environ. Pollut. 2011;159:3269-3282.

32. Balat $\mathrm{M}$ and Balat $\mathrm{H}$. Recent trends in global production and utilization of bio-ethanol fuel. Appl. Energ. 2009;86:2273-2282.

33. Lin Y, Tanaka S. Ethanol fermentation from biomass resources: current state and prospects. Appl. Microbiol. Biot. 2006;69: 627-642.

34. Menon V, Rao M. Trends in bioconversion of lignocellulose: biofuels, platform chemicals \& biorefinery concept. Pro. Energ. Combust. 2012;38:522-550.

35. Schwarz WH, Gapes JR. Butanol-rediscovering a renewable fuel. BioWorld Europe. 2006;1:16-19.

36. Gapes JR. The economics of acetone-butanol fermentation: theoretical and market considerations. J. Microbiol. Biotech. 2000;2:27-32.

37. NRDC. Growing energy. How biofuels can help end America's oil dependence [Internet]. New York: NRDC; c2004. Available from: http://www.bio.org/ind/Growing\%20Energy.pdf.

38. Balan V. Current challenges in commercially producing biofuels from Lignocellulosic biomass. ISRN Biotechnol. 2014.

39. Go AW, Conag AT, Igdon RMB, Toledo AS, Malila JS. Potentials of agricultural and agro-industrial crop residues for the displacement of fossil fuels: A Philippine context. Energ. Strateg. Rev. 2019;23:100-113.

40. REN21-Renewable Energy Policy Network for the 21st century [Internet]. http://www.ren21.net/REN21Activities/GlobalStatus Report.aspx

41. Mohr A, Raman S. Lessons from first generation biofuels and implications for the sustainability appraisal of second-generation biofuels. Energ. Policy. 2013;63:114-122.
42. Martin MA. First generation biofuels compete. N. Biotechnol. 2010;27:596-608.

43. Farrell AE, Brandt AR. Risks of the oil transition. Environ. Res. Lett. 2006;1:14004

44. Algieri A, Andiloro S, Tamburino V and Zema DA. The potential of agricultural residues for energy production in Calabria (Southern Italy). Renew. Sust. Ener. Rev.2019;104:1-14.

45. Fargione J, Hill J, Tilman D, Polasky S, Hawthorne P. Land clearing and the biofuel carbon debt. Science 2008;319: 1235-1238.

46. Searchinger T, Heimlich R, Houghton RA, et al. Use of US croplands for biofuels increases greenhouse gases through emissions from land-use change. Science 2008;319:1238-1240.

47. Eggers J, TrÖltzsch K, Falcucci A, et al. Is biofuel policy harming biodiversity in Europe? Gcb. Bioenerg. 2009;1:18-34.

48. Lee J, Yang X, Cho SH, et al. Pyrolysis process of agricultural waste using $\mathrm{CO}_{2}$ for waste management, energy recovery, and biochar fabrication. Appl. Energ. 2017;185;214-222.

59. Hellmann F, Verburg PH. Impact assessment of the European biofuel directive on land use and biodiversity. J. Environ. Manage. 2010;91:1389-1396.

50. Srivastava NSL, Narnaware SL, Makwana JP, Singh SN, Vahora S. Investigating the energy use of vegetable market waste by briquetting. Renew. Energ. 2014;6:270-275.

51. FitzPatrick M, Champagne P, Cunningham MF, Whitney RA. A biorefinery processing perspective: treatment of lignocellulosic materials for the production of value-added products. Bioresour. Technol. 2010;101:8915-8922.

52. Lipinsky ES. Chemicals from biomass: Petrochemical substitution options. Science 1981;212:1465-1471.

53. Frigon JC, Guiot SR. Biomethane production from starch and lignocellulosic crops: A comparative review. Biofuel Bioprod. Bior. 2010;4:447-458.

54. Vaish B, Sarkar A, Singh P, Singh PK, Sengupta C, Singh RP. Prospects of Biomethanation in Indian Urban Solid Waste: Stepping Towards a Sustainable Future. 2016. In: Karthikeyan O, Heimann K, Muthu S.eds. Recycling of Solid Waste for Biofuels and Bio-chemicals. Environmental Footprints and Eco-design of Products and Processes. Springer, Singapore

55. Callaghan FJ, Wase DAJ, Thayanithy K, Forster CF. Continuous co-digestion of cattle slurry with fruit and vegetable wastes and chicken manure. Biomass. Bioenerg. 2002;22:71-77.

56. Zheng Y, Yu C, Cheng YS, Zhang R, Jenkins B, Vander Gheynst JS. Effects of ensilage on storage and enzymatic degradability of sugar beet pulp. Bioresour. Technol. 2011;102:1489-1495.

57. Sarkar P, Bosneaga E, Auer M. Plant cell walls throughout evolution: towards a molecular understanding of their design principles. J. Exp. Bot. 2009;60:3615-3635.

58. Vaish B, Singh P, SrivastavaV, SinghPK, SinghRP. Municipal Solid Waste Management in India: Present Status and Energy Conversion Opportunities. 2016d. In: Singh DP, Kothari R and Tyagi VV.eds. Emerging Energy Alternatives for Sustainable Environment. New Delhi: TERI Press.

59. Bouallagui H, Lahdheb H, Romdan EB, Rachdi B, Hamdi M. Improvement of fruit and vegetable waste anaerobic digestion performance and stability with co-substrates addition. J. Environ. Manage. 2009;90:1844-1849. 
60. Dinuccio E, Balsari P, Gioelli F, Menardo S. Evaluation of the biogas productivity potential of some Italian agro-industrial biomasses. Bioresour. Technol. 2010;101:3780-3783.

61. Portugal-Pereira J, Soria R, Rathmann R, Schaeffer R, Szklo A. Agricultural and agro-industrial residues-to-energy: Techno-economic and environmental assessment in Brazil. Biomass. Bioenerg. 2015;81;521-533.

62. Piwowar A, Dzikuć M, Adamczyk J. Agricultural biogas plants in Poland-selected technological, market and environmental aspects. Renew. Sust. Energ. Rev. 2016;58:69-74.

63. Lebuhn M, Munk B and Effenberger M. Agricultural biogas production in Germany-from practice to microbiology basics. Energ. Sustain. Soc. 2014;4:10.

64. Hill DT and Bolte JP. Methane production from low solid concentration liquid swine waste using conventional anaerobic fermentation. Bioresour. Technol. 2000;74:241-247.

65. Vancanneyt M, De Vos P, Vennens L, De Ley J. Lactate and ethanol dehydrogenase activities in continuous cultures of Clostridium thermosaccharolyticum LMG 6564. Microbiology 1990;136:1945-1951.

66. Guerrero AB, Ballesteros I, Ballesteros M. The potential of agricultural banana waste for bioethanol production. Fuel 2018;213:176-185.

67. Evcan E, Tari C. Production of bioethanol from apple pomace by using cocultures: Conversion of agro-industrial waste to value added product. Energy 2015;88:775-782.

68. Domínguez-Bocanegra AR, Torres-Muñoz JA, López RA. Production of bioethanol from agro-industrial wastes. Fuel 2015;149:85-89.

69. Pareek D, Joshi A, Narnaware S, Verma VK. Operational experience of agro-residue briquettes-based power generation system of $100 \mathrm{~kW}$ capacity. Int. J. Renew. Energ. Res. 2012;2:477-485.

70. Pongthornpruek S, Sasitharanuwat A. The Utilization of bamboo residues and grease waste for charcoal briquette production. In: Applied Mechanics and Materials Trans Tech Publications. 2019;886:154-158.

71. Wilaipon P. The effect of briquetting pressure on banana-peel briquette and the banana waste in Northern Thailand. Am. J. Appl. Sci.2008;6:167-171.

72. Cho SH, Lee J, Kim KH, Jeon YJ, Kwon EE. Carbon dioxide assisted co-pyrolysis of coal and ligno-cellulosic biomass. Energ. Convers. Manage. 2016;118:243-252.

73. Roy MM, Corscadden KW. An experimental study of combustion and emissions of biomass briquettes in a domestic wood stove. Appl. Energ. 2012;99:206-212.

74. Rajaseenivasan T, Srinivasan V, Qadir GSM, Srithar K. An investigation on the performance of sawdust briquette blending with neem powder. Alexandria Eng. 2016;55:2833-2838.

75. Romallosa ARD, Kraft E. Feasibility of Biomass Briquette Production from Municipal Waste Streams by Integrating the Informal Sector in the Philippines. Resources 2017;6:12.

76. Wilson DC, Velis C, Cheeseman C. Role of informal sector recycling in waste management in developing countries. Habitat. Int. 2006;30:797-808.

77. Emerhi C. Physical and combustion properties of briquettes produced from sawdust of three hardwood species and different organic binders. Adv. Appl. Sci. Res. 2011;2:236-246.
78. Grover PD, Mishra SK, Clancy JS. Development of an appropriate biomass briquetting technology suitable for production and use in developing countries. Energ. Sustain. Dev. 1994;1:45-48.

79. Yu H, Huang GH. Effects of sodium as a pH control amendment on the composting of food waste. Bioresour. Technol. 2009;100:2005-11.

80. Pilusa TJ, Huberts R, Muzenda E. Low pressure binder-less densification of fibrous biomass material using a screw press. World. Acad. Sci. Eng. Technol. 2012;6:657-660.

81. McHenry MP. Agricultural bio-char production, renewable energy generation and farm carbon sequestration in Western Australia: Certainty, uncertainty and risk. Agric. Ecosyst. Environ. 2009;129:1-7.

82. Guo XM, Trably E, Latrille E, Carrere H, Steyer JP. Hydrogen production from agricultural waste by dark fermentation: A review. Int. J. Hydrogen. Energ. 2010;35:10660-10673.

83. Brentner LB, Peccia J, Zimmerman JB. Challenges in developing biohydrogen as a sustainable energy source: Implications for a research agenda. Environ. Sci. Technol.2010;44:2243-2254.

84. Ivanova G, Rákhely G, Kovács KL. Thermophilic biohydrogen production from energy plants by Caldicellulosiruptor saccharolyticus and comparison with related studies. Int. J. Hydrogen. Energ. 2009;34:3659-3670.

85. Sovacool BK. Energy policymaking in Denmark: Implications for global energy security and sustainability. Energ. Policy 2013;61:829-839.

86. Nath K, Muthukumar M, Kumar A, Das D. Kinetics of two-stage fermentation process for the production of hydrogen. Int. J. Hydrogen. Energ. 2008;33:1195-1203.

87. Karakashev D, Kotay SM, Trably E, Angelidaki I. A strict anaerobic extreme thermophilic hydrogen-producing culture enriched from digested household waste. J. Appl. Microbiol. 2009;106: 1041-1049.

88. Puyol D, Batstone DJ, Hülsen T, Astals S, Peces M, Krömer JO. Resource recovery from wastewater by biological technologies: Opportunities, challenges, and prospects. Front Microbiol. 2017;7:2106.

89. Chandrasekhar K, Lee YJ, Lee DW. Biohydrogen production: Strategies to improve process efficiency through microbial routes. Int. J. Mol. Sci. 2015;16:8266-8293.

90. Chandrasekhar K, Mohan SV. Induced catabolic bio-electrohydrolysis of complex food waste by regulating external resistance for enhancing acidogenic biohydrogen production. Bioresour. Technol. 2014;165:372-382.

91. Eddine BT, Salah MM. Solid waste as renewable source of energy: Current and future possibility in Algeria. Int. J. Energy. Environ. Eng. 2012;3:1-12.

92. Khatiwada D, Seabra J, Silveira S, Walter A. Power generation from sugarcane biomass-A complementary option to hydroelectricity in Nepal and Brazil. Energy 2012;48:241-254.

93. Wiesenthal T, Mourelatou A, Petersen J. How much bioenergy can Europe produce without harming the environment? EEA Report. 2006.

94. Mu"nster M, Meibom P. Optimization of use of waste in the future energy system. Energy 2011;36:1612-1622.

95. Gadde B, Menke C, Wassmann R. Rice straw as a renewable energy source in India, Thailand, and the Philippines: Overall 
potential and limitations for energy contribution and greenhouse gas mitigation. Biomass Bioenerg. 2009;33:1532-1546.

96. Mehta CM, Khunjar WO, Nguyen V, Tait S, Batstone DJ. Technologies to recover nutrients from waste streams: A critical review. Crit. Rev. Env. Sci. Tec. 2015;45:385-427.

97. Woods J, Williams A, Hughes JK, Black M, Murphy R. Energy and the food system. Philos. T. Roy. Soc. B. 2010;365:2991-3006.

98. Cordell D, Drangert JO, White S. The story of phosphorus: Global food security and food for thought. Global Environ. Chang. 2009;19:292-305.

99. Jasinski SM. Phosphate rock. U.S. Geological Survey, Mineral Commodity Summaries [Internet]. 2012. Available from: http://minerals.usgs.gov/minerals/pubs/commodity/phosphate rock/mcs-2012-phosp.pdf.

100. Urrutia O, Erro J, Zabini A, et al. New amphiphilic composite for preparing efficient coated potassium-fertilizers for top-dressing fertilization of annual crops. J. Agric. Food. Chem. 2018;66:4787-4799.

101. Giacalone D, Wendin K, Kremer S, et al. Health and quality of life in an aging population-Food and beyond. Food Qual. Prefer. 2016;47:166-170.

102. Sharma B, Sarkar A, Singh P, Singh RP. Agricultural utilization of biosolids: A review on potential effects on soil and plant grown. Waste. Manage. 2017;64:117-132.

103. Verstraete W, Clauwaert P, Vlaeminck SE. Used water and nutrients: Recovery perspectives in a 'panta rhei'context. Bioresour. Technol. 2016;215:199-208.

104. Carey DE, Yang Y, McNamara PJ, Mayer BK. Recovery of agricultural nutrients from biorefineries. Bioresour. Technol. 2016;215:186-198.

105. Rahgozar MA, Saberian M, Li J. Soil stabilization with non-conventional eco-friendly agricultural waste materials: An experimental study. Transport. Geotech. 2018;14:52-60.

106. Mor S, Chhoden K, Ravindra K. Application of agro-waste rice husk ash for the removal of phosphate from the wastewater. J. Clean. Prod. 2016;129:673-680.

107. Cordell D, Rosemarin A, Schröder JJ, Smit AL. Towards global phosphorus security: A systems framework for phosphorus recovery and reuse options. Chemosphere 2011;84:747-758.

108. Siciliano A, Limonti C, Mehariya S, Molino A, Calabrò V. Biofuel Production and Phosphorus Recovery through an Integrated Treatment of Agro-Industrial Waste. Sustainability 2019;11:52.

109. Batstone DJ, Hülsen T, Mehta CM, Keller J. Platforms for energy and nutrient recovery from domestic wastewater: A review. Chemosphere 2015;140:2-11.

110. Wang Y, Zheng SJ, Pei LY, Ke L, Peng DC, Xia SQ. Nutrient release, recovery and removal from waste sludge of a biological nutrient removal system. Environ. Technol. 2014;35:2734-2742.

111. Parsons SA, Smith JA. Phosphorus removal and recovery from municipal wastewaters. Elements 2008;4:109-112.

112. Li N, Wang X, Ren N, Zhang K, Kang H, You S. Effects of solid retention time (SRT) on sludge characteristics in enhanced biological phosphorus removal (EBPR) reactor. Chem. Biochem. Eng. Q. 2008;22:453-458.

113. Tarayre C, De Clercq L, Charlier R, et al. New perspectives for the design of sustainable bioprocesses for phosphorus recovery from waste. Bioresour. Technol. 2016;206:264-274.

114. Demirer S, Demirer GN, Chen S. Ammonia removal from anaerobically digested dairy manure by struvite precipitation. Proc. Biochem. 2005;40:3667-3674.

115. Shen Y, Ogejo JA, Bowers KE. Abating the effects of calcium on struvite precipitation in liquid dairy manure. Trans. ASABE 2011;54:325-336.

116. Huang HM, Xiao XM, Yang LP, Yan B. Removal of ammonium from rare-earth wastewater using natural brucite as a magnesium source of struvite precipitation. Water. Sci. Technol. 2011;63:468-474.

117. Liu Y, Kwag JH, Kim JH, Ra C. Recovery of nitrogen and phosphorus by struvite crystallization from swine wastewater. Desalination 2011;277:364-369.

118. Yetilmezsoy K and Sapci-Zengin Z. Recovery of ammonium nitrogen from the effluent of UASB treating poultry manure wastewater by MAP precipitation as a slow release fertilizer. J. Hazard. Mater. 2009;166:260-269.

119. Prabhu M, Mutnuri S. Cow urine as a potential source for struvite production. Int. J. Recycl. Org. Waste. Agric. 2014;3:49.

120. Kataki S, West H, Clarke M, Baruah DC. Phosphorus recovery as struvite from farm, municipal and industrial waste: Feedstock suitability, methods and pre-treatments. Waste Manage. 2016;49:437-454.

121. KöseTE, Kıvanç B. Adsorption of phosphate from aqueous solutions using calcined waste eggshell. Chem. Eng. J. 2011;178:34-39.

122. SzogiAA, Vanotti MB and Ro KS. Methods for treatment of animal manures to reduce nutrient pollution prior to soil application. Curr. Pollut. Rep.2015;1:47-56.

123. Siciliano A and Rosa SD. Recovery of ammonia in digestates of calf manure through a struvite precipitation process using unconventional reagents. Environ. Technol. 2014;35:841-850.

124. Qiu G, Ting YP. Direct phosphorus recovery from municipal wastewater via osmotic membrane bioreactor (OMBR) for wastewater treatment. Bioresour. Technol. 2014;170:221-229.

125. Padrino B, Lara-Serrano M, Morales-delaRosa S, et al. Resource recovery potential from lignocellulosic feedstock upon lysis with ionic liquids. Front. Bioeng. Biotechnol. 2018;6:119.

126. Yan F, Sun Y, Hui X, et al. The effect of straw mulch on nitrogen, phosphorus and potassium uptake and use in hybrid rice. Paddy. Water Environ. 2019;17:23-33.

127. Puyol D, Batstone DJ, Hülsen T, Astals S, Peces M, Krömer JO. Resource recovery from wastewater by biological technologies: opportunities, challenges, and prospects. Front. Microbiol. 2017;7:2106.

128. Wilson RS, Schlea DA, Boles CM, Redder TM. Using models of farmer behavior to inform eutrophication policy in the Great Lakes. Water Res. 2018;139:38-46.

129. Cottingham KL, Ewing HA, Greer ML, Carey CC, Weathers KC. Cyanobacteria as biological drivers of lake nitrogen and phosphorus cycling. Ecosphere 2015;6:1-19

130. Capodaglio AG, Hlavínek P, Raboni M. Physico-chemical technologies for nitrogen removal from wastewaters: A review. Rev. Ambiente. Agua. 2015;10:481-498.

131. Williams AT, Zitomer DH, Mayer BK. Ion exchange-precipitation for nutrient recovery from dilute 
wastewater. Environ. Sci. Water. Res. Technol.2015;1:832-838.

132. Samatya S, Kabay N, Yüksel Ü, Arda M, Yüksel M. Removal of nitrate from aqueous solution by nitrate selective ion exchange resins. React. Funct. Polym. 2006;66:1206-1214.

133. Gohlke O, Weber T, Seguin P, Laborel Y. A new process for NOx reduction in combustion systems for the generation of energy from waste. Waste Manage. 2010;30:1348-1354.

134. Fox MG, Keast A. Effects of winterkill on population structure, body size, and prey consumption patterns of pumpkinseed in isolated beaver ponds. Can. J. Zool. 1990;68:2489-2498.

135. Ladd JN, Oades JM, Amato M. Distribution and recovery of nitrogen from legume residues decomposing in soils sown to wheat in the field. Soil. Biol. Biochem. 1981;13:251-256.

136. Adeoye GO, Sridhar MKC, Ipinmoroti RR. Potassium recovery from farm wastes for crop growth. Commun. Soil. Sci. Plan. 2001;32:2347-2358.

137. Hanc A, Chadimova Z. Nutrient recovery from apple pomace waste by vermicomposting technology. Bioresour. Technol. 2014;168:240-244.

138. Swarnam TP, Velmurugan A, Pandey SK, Roy SD. Enhancing nutrient recovery and compost maturity of coconut husk by vermicomposting technology. Bioresour. Technol. 2016;207: 76-84.

139. Aynehband A, Gorooei A, Moezzi AA. Vermicompost: An eco-friendly technology for crop residue management in organic agriculture. Energ. Proced. 2017;141:667-671

140. Bolzonella D, Fatone F, Gottardo M, Frison N. Nutrients recovery from anaerobic digestate of agro-waste: Techno-economic assessment of full-scale applications. J. Environ. Manage. 2018;216:111-119.

141. Gienau T, Brüß U, Kraume M, Rosenberger S. Nutrient recovery from biogas digestate by optimised membrane treatment. Waste. Biomass. Valori. 2018;9:2337-2347.

142. Sharma K, Garg VK. Comparative analysis of vermicompost quality produced from rice straw and paper waste employing earthworm Eisenia fetida (Sav.). Bioresour. Technol. 2018;250:708-715.

143. Cofie O, Veenhuizen VR, de Vreede V, Maessen S. Waste management for nutrient recovery: Options and challenges for urban agriculture. Urban Agric. Magazine. 2010;23:3-7.

144. Adamtey N, Cofie O, Forster D. An economic analysis of co-compost-fertilizer mixture (comlizer) use on maize production in the Accra plain of Ghana. 2009. Research Progress Report Submitted to IWMI and Eawag/Sandec. 10

145. Kemppainen AJ, Shonnard DR. Comparative life-cycle assessments for biomass-to-ethanol production from different regional feedstocks. Biotechnol. Progr. 2005;21:1075-1084.

146. Claassen PAM, Van Lier JB, Contreras AL, et al. Utilisation of biomass for the supply of energy carriers. Appl. Microbiol. Biotechnol. 1999;52:741-755.

147. Galbe M, Zacchi G. A review of the production of ethanol from softwood. Appl Microbiol. Biotechnol. 2002;59:618-628.

148. Pan X, Arato C, Gilkes N, et al. Biorefining of softwoods using ethanol organosolv pulping: Preliminary evaluation of process streams for manufacture of fuel-grade ethanol and co-products. Biotechnol. Bioeng. 2005;90:473-481.

149. Dassanayake GDM, Kumar A. Techno-economic assessment of triticale straw for power generation. Appl. Energ.2012;98: 236-245.

150. Seabra JE, Tao L, Chum HL, Macedo IC. A techno-economic evaluation of the effects of centralized cellulosic ethanol and co-products refinery options with sugarcane mill clustering. Biomass. Bioenerg. 2010;34:1065-1078.

151. Yoosin S, Sorapipatana CA. Study of ethanol production cost for gasoline substitution in Thailand and its competitiveness. Thammasat. Int. J. Sci. Technol.2007;12:69-80.

152. Kojima M, Johnson T. Potential for biofuels for transport in developing countries. 2005. Energy sector management assistance program, Joint UNDP/ World Bank, Washington, D.C.

153. Mitchel D. A note on rising food prices. 2008. World bank development prospects group, World Bank, Washington, DC

154. Christensen K, Smith A. The case for hemp as a biofuel. 2008. Vote Hemp Inc. Report, Brattleboro, VT

155. Srivastava V, De Araujo ASF, Vaish B, Bartelt-Hunt S, Singh $\mathrm{P}$, Singh RP. Biological response of using municipal solid waste compost in agriculture as fertilizer supplement. Rev. Environ. Sci. Biol. 2016;15:677-696.

156. Srivastava V, Gupta SK, Singh P, Sharma B, Singh RP. Biochemical, physiological, and yield responses of lady's finger (Abelmoschus esculentus L.) grown on varying ratios of municipal solid waste vermicompost. Int. J. Recycl. Org. Waste Agric. 2018;7:241-250.

157. Bekchanov M, Mirzabaev A. Circular economy of composting in Sri Lanka: Opportunities and challenges for reducing waste related pollution and improving soil health. J. Clean. Prod. 2018;202:1107-1119.

158. Dockhorn T. About the economy of phosphorus recovery. In: Mavinic D, Koch F, Ashley S, eds. London; IWA Publishing: 2009. p. 132-16.

159. Battistoni P, Bocadoro R, Fatone F, Pavan P. Auto-nucleation and crystal growth of struvite in a demonstrative fluidized bed reactor (FBR). Environ. Technol. 2005;26:975-982.

160. Blumenstein B, Bühle L, Wachendorf M, Möller D. Economic assessment of the integrated generation of solid fuel and biogas from biomass (IFBB) in comparison to different energy recovery, animal-based and non-refining management systems. Bioresour. Technol. 2012;119:312-323.

161. Cowburn G, Stockley L. Consumer understanding and use of nutrition labelling: A systematic review. Public Health Nutr. 2005;8:21-28.

162. Mitchell C, Bauknecht D, Connor PM. Effectiveness through risk reduction: A comparison of the renewable obligation in England and Wales and the feed-in system in Germany. Energ. Policy 2006;34:297-305.

163. Sawin J. National policy instruments: Policy lessons for the advancement and diffusion of renewable energy technologies around the world. 2004. Thematic Background Paper. In: Proceedings of the International Conference for Renewables, Bonn.

164. Mendonça M, Tariffs FI. Accelerating the deployment of renewable energy. London: Earthscan; 2007.

165. Butler L, Neuhoff K. Comparison of feed-in tariff, quota and auction mechanisms to support wind power development. Renew. Energ. 2008;33:1854-1867. 
166. Langniss O, Wiser R. The renewables portfolio standard in Texas: An early assessment. Energ. policy. 2003;31:527-535.

167. Mitchell C. The England and Wales non-fossil fuel obligation: History and lessons. Annu. Rev. Energ. Environ. 2000;25: 285-312.

168. Fischer C, Newell RG. Environmental and technology policies for climate mitigation. J. Environ. Econ. Manage. 2008;55: 142-162.

169. Jaffe AB, Stavins RN. Dynamic incentives of environmental regulations: The effects of alternative policy instruments on technology diffusion. J. Environ. Econ. Manage. 1995;29:
S43-S63.

170. Jaffe AB, Newell RG, Stavins RN. Technological change and the environment. 2003. In: Maler, K.G. Vincent JR. eds. Handbook of Environmental Economics.

171. Popp D. Induced innovation and energy prices. Am. Econ. Rev. 2002;92:160-180.

172. Klassen RD, Roberge PR, Lafront AM, Oteyaka MO, Ghali E. Corrosion behaviour of zinc and aluminum magnesium alloys by scanning reference electrode technique (SRET) and electrochemical noise (EN). Can. Metall. Quart. 2005;44:47-52. 